\begin{abstract}
Ahmad Nur Bakhtiar
Mahasiswa Magister Ilmu Pemerintahan

Universitas Muhammadiyah Yogyakarta

Email: ahmadbahtiar667@yahoo.co.id
\end{abstract}

\section{Zuly Qodir}

Dosen Magister IImu Pemerintahan Universitas Muhammadiyah Yogyakarta Email : zuly_qodir@yahoo.com

http://dx.doi.org/10.18196/

igpp.2015.0032
Implementasi Program Keluarga Harapan Sebagai Upaya Penanggulangan Kemiskinan di Kecamatan Berbah Sleman Tahun 2013

\begin{abstract}
The study aims to determine the implementation and the factors that play a role in the PKH program conducted in the district Berbah 2013. The research method used is descriptive qualitative research. Data was collected through interviews and documentation. The data analysis done by qualitative descriptive. The results showed: 1 . Aspects of compliance in the implementation of CCT programs in the district Berbah can be seen from: a). PKH implementation rules in the district Berbah besides the rules of the center, are also required to attend group meetings, b). Commitment to the rule implementing CCT implementation in districts Berbah year 2013 has been very good, c). Implementing compliance in implementing the phases of activity in the district PKH Berbah in 2013 is good, and 2. Factors that play a role in the implementation of the poverty reduction program (PKH) in the district Berbah in 2013: a). Resource; to source funds using budget funds I, II budget, and governmental organizations, and to human resources from the district level up to the hamlet level has been good, b). Communication fellow companion if no help each activity, c). Implementing attitude if there are conditions on the ground which is not in accordance with the rules of implementation of the CCT, the immediate improvement to validate the data, d). Socio-economic conditions of communities in the district Berbah fish farmers have had good production, the trade sector has also been improved.

Keywords: Program Implementation, Poverty Alleviation Program, the Family Hope Program (PKH).
\end{abstract}

\begin{abstract}
ABSTRAK
Penelitian bertujuan untuk mengetahui implementasi dan faktor-faktor yang berperan dalam program PKH yang dilakukan di kecamatan Berbah tahun 2013. Metode penelitian yang digunakan adalah penelitian deskriptif kualitatif. Teknik pengumpulan data dilakukan dengan wawancara dan dokumentasi. Teknik analisa data dilakukan dengan deskriptif kualitatif. Hasil penelitian menunjukkan: 1. Aspek kepatuhan dalam implemetasi program PKH di kecamatan Berbah dapat dilihat dari: a). Aturan pelaksanaan PKH di kecamatan Berbah selain aturan dari pusat, juga diwajibkan untuk mengikuti pertemuan kelompok, b). Komitmen pelaksana terhadap aturan pelaksanaan PKH di kecamatan Berbah tahun 2013 sudah sangat baik, c). Kepatuhan pelaksana dalam melaksanakan tahapan kegiatan PKH di kecamatan Berbah tahun 2013 sudah bagus, dan 2. Faktor yang berperan dalam implementasi program penanggulangan kemiskinan (PKH) di kecamatan Berbah tahun 2013: a). Sumberdaya; untuk sumber dana dengan menggunakan dana APBD I, APBD II, dan swadaya masyarakat, dan untuk sumberdaya manusia dari tingkat kecamatan sampai dengan tingkat pedukuhan sudah baik, b). Komunikasi sesama pendamping kalau ada kegiatan saling bantu membantu, c). Sikap Pelaksana apabila ada kondisi di lapangan yang tidak sesuai dengan aturan pelaksanaan PKH, maka segera dilakukan perbaikan dengan melakukan validasi data, d). Kondisi Sosial Ekonomi Masyarakat di kecamatan Berbah petani-petani ikan produksinya sudah bagus, sektor perdagangan juga sudah membaik.

Kata Kunci: Implementasi Program, Program Pengentasan Kemiskinan, Program Keluarga Harapan (PKH).
\end{abstract}




\section{PENDAHULUAN}

Strategi besar Pemerintah Indonesia dalam pembangunan nasional adalah dengan menerapkan Four Track Strategy, yaitu: pro growth, pro job, pro poor, dan pro environment (Firmansyah, 2012). Strategi 4 jalur ini ditujukan untuk mendorong pertumbuhan ekonomi yang berkeadilan (growth with equity) melalui perluasan kesempatan kerja, pengurangan tingkat kemiskinan, dan menjaga pertumbuhan yang berkelanjutan dengan menekankan pada kelestarian lingkungan. Melalui strategi tersebut diharapkan persoalan kesenjangan juga dapat semakin dikurangi. Agenda besar pembangunan nasional tersebut telah termuat dalam Rencana Pembangunan Jangka Menengah (RPJMN) 2004-2009 dan 20102014. Hal ini dipertegas kembali dalam rencana pembangunan nasional yang tertuang dalam RKP 2013yang mengangkat tema "Memperkuat Perekonomian Domestik bagi Peningkatan dan Perluasan Kesejahteraan Rakyat" (RPJM 2010-2014).

Strategi Pemerintah dalam mengurangi kemiskinan difokuskan melalui 3 klaster program penanggulangan kemiskinan, yaitu (Kementerian Komunikasi dan Informasi RI, 2011):

1. Klaster Pertama: Program bantuan dan perlindungan sosial terpadu berbasis keluarga, yang bertujuan untuk melakukan pemenuhan hak dasar, mengurangi beban pengeluaran keluarga miskin, dan perbaikan kualitas hidup keluarga miskin. Program utamanya adalah Beras Miskin (Raskin), Jamkesmas, Program Keluarga Harapan (PKH), Bantuan Operasional Sekolah (BOS), dan Bantuan Siswa Miskin (BSM).

2. Klaster Kedua: Program penanggulangan kemiskinan berbasis pemberdayaan masyarakat melalui program PNPM Mandiri yang bertujuan untuk mengembangkan potensi dan memperkuat kapasitas kelompok masyarakat miskin untuk terlibat dalam pembangunan, meningkatkan pendapatan dan taraf hidup masyarakat melalui usaha dan bekerja bersama untuk mencapai 
keberdayaan dan kemandirian dengan sasaran kelompok masyarakat/kecamatan miskin.

3. Klaster Ketiga: Program penanggulangan kemiskinan berbasis pemberdayaan usaha ekonomi mikro dan kecil (UMK) yang bertujuan untuk membuka dan memberikan akses permodalan dan penguatan ekonomi bagi pelaku usaha berskala mikro dan kecil dengan program Kredit Usaha Rakyat (KUR).

Melalui pembagian klaster bertingkat tersebut diharapkan kelompok keluarga miskin yang awalnya menjadi penerima program klaster 1 akan dapat memenuhi kebutuhan dasarnya dan selanjutnya naik kelas menjadi penerima program klaster 2 untuk terus memperbaiki kehidupannya hingga mampu memanfaatkan program klaster 3 dan akhirnya diharapkan dapat keluar dari jeratan masalah kemiskinan. Untuk memperkuat strategi 3 klaster tersebut, Pemerintah sejak tahun 2011 meluncurkan Klaster Keempat yang terdiri dari Program Rumah Murah, Transportasi Umum Murah, Air Bersih untuk Rakyat, Listrik Murah dan Hemat, serta Peningkatan Kehidupan Nelayan dan Masyarakat Pinggir Perkotaan (Kementerian Komunikasi dan Informasi RI, 2011).

Kecamatan Berbah meliputi wilayah seluas 2.299,00 ha, atau merupakan kecamatan dengan wilayah tersempit di Kabupaten Sleman. Secara administratif Kecamatan Berbah terbagi ke dalam empat Desa, yaitu Sendangtirto, Tegaltirto, Jogotirto dan Kalitirto. Dari keempat desa tersebut, Jogotirto menempati wilayah terluas, yaitu 621,00 ha, sedangkan wilayah tersempit adalah Sendangtirto, yang meliputi kawasan seluas 522, 00 ha.

Secara umum, ekonomi di Kecamatan Berbah digerakkan oleh sektor yang terkait dengan pertanian, dan sektor non-pertanian. Aktivitas pertanian di kawasan ini sebagian besar dilakukan di atas tanah sawah irigasi teknis, yang meliputi kawasan seluas 1.219,50 ha. Di atas lahan ini ditanam padi dan palawija. Sistem irigasi di kawasan ini berjalan dengan baik dengan beroperasinya dua 
bendungan irigasi masing-masing di Sungai Opak dan Sungai Kuning. Aliran air yang teratur, terutama pada musim-musim hujan, menyebabkan tanah sawah di kawasan ini dapat memanen padi sebanyak 2 sampai 3 kali per tahun, dan 1 sampai 2 kali panen palawija. Dilihat dari kepemilikan tanah per rumah tangga dapat disimpulkan bahwa sebagian besar petani di Kecamatan Berbah adalah petani kecil, yang memiliki tanah kurang dari 0,25 ha, yaitu sebanyak 1.481 orang. Sementara itu hanya ada 45 rumah tangga yang memiliki tanah lebih dari 1,25 ha.

Selain oleh sektor pertanian, ekonomi di Kecamatan Berbah juga digerakkan oleh sektor non-pertanian, yaitu sektor industri dan jasa. Terdapat tiga industri besar yang berlokasi di Desa Kalitirto dan Sendangtirto; empat industri skala sedang yang masing-masing berlokasi di Desa Jogotirto, Tegaltirto dan Kalitirto. Selain itu terdapat usaha pertambangan, yaitu tanah liat dan batu putih. Pertambangan tanah liat ini dimanfaatkan untuk pembuatan batu bata. Sektor jasa yang terdapat di kawasan ini antara lain usaha angkutan umum (bis), pertukangan kayu, pertukangan batu, cukur, jahit, salon kecantikan, perbengkelan, penggilingan padi, toko, dan warung makan. Di antara usaha-usaha jasa tersebut, pertukangan batu adalah yang paling menonjol, yaitu dengan jumlah 591 buah.

Ada empat faktor atau variabel yang merupakan syarat terpenting guna berhasilnya proses implementasi. Keempat faktor tersebut adalah 1) Komunikasi, 2) Sumber daya (resources), 3) Disposisi dan 4) Struktur birokrasi (Dwiyanto, 2009: 10). Sedangkan menurut Donald P. Warwieck (1988:17) dalam tahap implementasi program terdapat dua faktor yang mempengaruhi keberhasilan suatu proyek yaitu faktor pendorong (facilitating conditions) dan faktor penghambat (impeding conditions). Berdasarkan uraian diatas, peneliti tertarik untuk mengadakan penelitian lebih lanjut mengenai bagaimana implementasi program penanggulangan kemiskinan $\mathrm{PKH}$ yang dilakukan di Kecamatan Berbah. 


\section{KERANGKA TEORI}

\section{KEBIJAKAN PUBLIK}

Berdasarkan kamus Administrasi Publik (Chandler dan Plano, 1988:107) (dalam Keban, 2004:56), kebijakan publik adalah pemanfaatan yang strategis terhadap sumber daya-sumber daya yang ada untuk memecahkan masalah-masalah publik atau pemerintah. Chandler dan Plano beranggapan bahwa kebijakan publik merupakan suatu bentuk intervensi yang kontinum oleh pemerintah demi kepentingan orang-orang yang tidak berdaya dalam masyarakat agar mereka dapat hidup dan ikut berpartisipasi dalam pemerintah.

Definisi dari kebijakan publik tersebut dapat dirangkum menjadi beberapa konsep kunci yang termuat dalam kebijakan publik seperti diungkapkan Young dan Quinn (dalam Suharto, 2008:44-45), sebagai berikut:

1. Tindakan pemerintah yang berwenang. Kebijakan publik adalah tindakan yang dibuat dan diimplementasikan oleh Badan Pemerintah yang memiliki kewenangan hukum, politis dan finansial untuk melakukannya.

2. Sebuah reaksi terhadap kebutuhan dan masalah dunia nyata. Kebijakan publik berupaya merespon masalah atau kebutuhan konkrit yang berkembang dalam masyarakat.

3. Seperangkat tindakan yang berorientasi tujuan. Kebijakan publik biasanya bukanlah sebua

4. h keputusan yang tunggal, melainkan terdidi dari beberapa pilihan tindakan atau strategi yang dibuat untuk mencapai tujuan tertentu demi kepentingan orang banyak.

5. Sebuah keputusan untuk melakukan atau tidak melakukan sesuatu. Kebijakan publik pada umumnya merupakan tindakan korektif untuk memecahkan masalah sosial. Namun, kebijakan publik bisa juga dirumuskan berdasar keyakinan bahwa masalah sosial akan dapat dipecahkan oleh kerangka yang sudah ada dan 
karenanya tidak memerlukan tindakan tertentu.

6. Sebuah justifikasi yang dibuat oleh seorang atau beberapa orang aktor. Kebijakan publik berisi sebuah pernyataan atau justifikasi terhadap langkah-langkah atau rencana tindakan yang telah dirumuskan, bukan sebuah maksud atau janji yang belum dirumuskan. Keputusan yang telah dirumuskan dalam kebijakan publik bisa dibuat oeh sebuah badan pemerintah, maupun oleh beberapa perwakilan lembaga pemerintah.

Jika melihat dari beberapa teori dari para ahli tentang kebijakan publik tersebut, dapat disimpulkan bahwa program-program penanggulangan kemiskinan di kabupaten Sleman merupakan suatu kebijakan publik. Program TKPK suatu program yang dibuat dan diimplementasikan oleh Pemerintah Republik Indonesia Nasional, TKPK Provinsi, dan TKPK Kabupaten/Kota, berdasarkan Peraturan Presiden Nomor 54 Tahun 2005, dimaksudkan untuk menjalankan fungsi koordinasi penanggulangan kemiskinan dengan melakukan langkah-langkah konkret untuk mengkoordinasikan seluruh program penanggulangan kemiskinan, baik program-program yang dilaksanakan oleh Pemerintah Pusat melalui Kementerian/Lembaga dan Pemerintah Daerah.

\section{IMPLEMENTASI KEBIJAKAN}

Implementasi adalah aktifitas-aktifitas yang dilakukan untuk melaksanakan suatu kebijakan secara efektif, implementasi ini merupakan pelaksanaan aneka ragam program yang dimaksudkan dalam sesuatu kebijakan. Menurut Syukur Abdullah (1988: 398) bahwa pengertian dan unsur-unsur pokok dalam proses implementasi sebagai berikut:

1. Proses implementasi program/kebijakan ialah rangkaian kegiatan tindak lanjutyang terdiri atas pengambilan keputusan, langkahlangkah yang strategismaupun operasional yang ditempuh guna mewujudkan suatu program ataukebijaksanaan menjadi 
kenyataan, guna mencapai sasaran dari programyang ditetapkan semula.

2. Proses implementasi dalam kenyataan yang sesungguhnya dapatberhasil, kurang berhasil ataupun gagal sama sekali ditinjau dari hasilyang dicapai atau "outcomes" unsur yang pengaruhnya dapat bersifatmendukung maupun menghambat sasaran program.

3. Dalam proses implementasi sekurang-kurangnya terdapat tiga unsur yangpenting dan mutlak yaitu:

a. Implementasi program atau kebijaksanaan tidak mungkindilaksanakan dalam ruang hampa. Oleh karena itu faktor lingkungan(fisik, sosial budaya dan politik) akan mempengaruhi prosesimplementasi program- program pembangunan pada umumnya.

b. Target groups yaitu kelompok yang menjadi sasaran dan diharapkanakan menerima manfaat dari program tersebut.

c. Adanya program kebijaksanaan yang dilaksanakan.

d. Strategi perorangan yang bertanggungjawab dalam pengelolaan,pelaksanaan dan pengawasan implementasi tersebut.

Menurut pendapat William N.Dunn (1992: 80), implementasi kebijaksanaan berarti pelaksanaan dan pengendalian arah tindakan kebijaksanaan sampai dicapainya hasil kebijaksanaan.

\section{MODEL-MODEL IMPLEMENTASI}

A. MODEL GEORGE C EDWARD III

Menurut Edward III, implementasi kebijakan dipengaruhi oleh empat variable, yakni:
(1) Komunikasi,
(2) Sumberdaya,
(3) Disposisi, 
(4) Struktur birokrasi.

Keempat variable tersebut saling berhubungan satu sama lain. Model tersebut dapat dilihat pada gambar di bawahini:

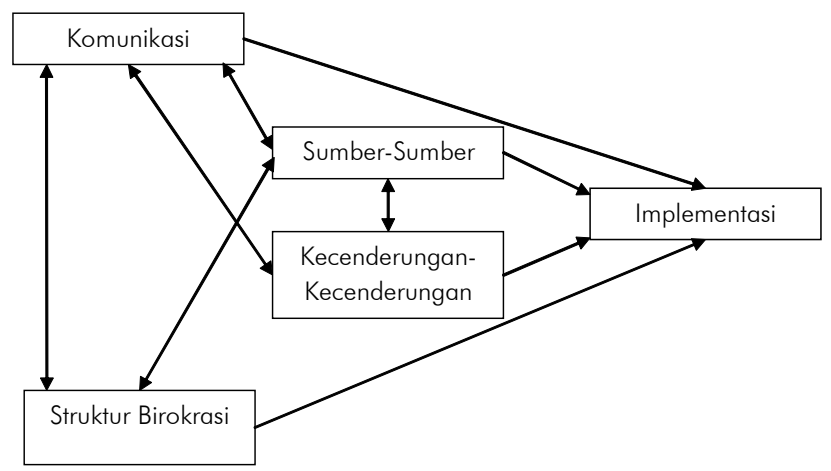

GAMBAR 1. MODEL IMPLEMENTASI DARI EDWARDS III (Sumber: Mutiarin dan Zainudin, 2014:44)

Variabel yang pertama adalah komunikasi. Implemetasi yang efektif terjadi apabila para pembuat keputusan sudah mengetahui apa yang akan mereka kerjakan. Pengetahuan atas apa yang akan mereka kerjakan dapat berjalan apabila komunikasi berjalan dengan baik, sehingga setiap keputusan kebijakan dan peraturan implemetasi harus dikomunikasikan kepada personil yang tepat. Selain itu, kebijakan yang dikomunikasikanpun harus tepat, akurat, dan konsisten. Komunikasi diperlukan agar para pembuat keputusan dan para implementator akan semakin konsisten dalam melaksanakan setiap kebijakan yang akan diterapkan dalam masyarakat.

\section{B. MODEL VAN METER DAN VAN HORN}

Implementasi kebijakan menurut Van Horn dan Van Meter (1975:447) adalah suatu tindakan yang dilakukan oleh pemerintah maupun swasta baik secara individu maupun kelompok untuk mencapai tujuan sebagai mana dirumuskan di dalam kebijakan. Proses implementasi ini merupakan sebuah abstraksi atau 
perfomansi suatu implementasi kebijakan yang pada dasarnya secara sengaja dilakukan untuk meraih kinerja implementasi kebijakan publik yang tinggi yang berlangsung dalam berbagai variabel. Dalam pelaksanaannya diperlukan standar atau aturan baku untuk melihat kinerja dan keberhasilan implementasinya. Model ini mengandaikan bahwa implementasi kebijakan berjalan secara linier dari keputusan politik yang tersedia, pelaksana, dan kinerja kebijakan publik.

Untuk lebih jelasnya dapat dilihat pada gambar berikut ini:

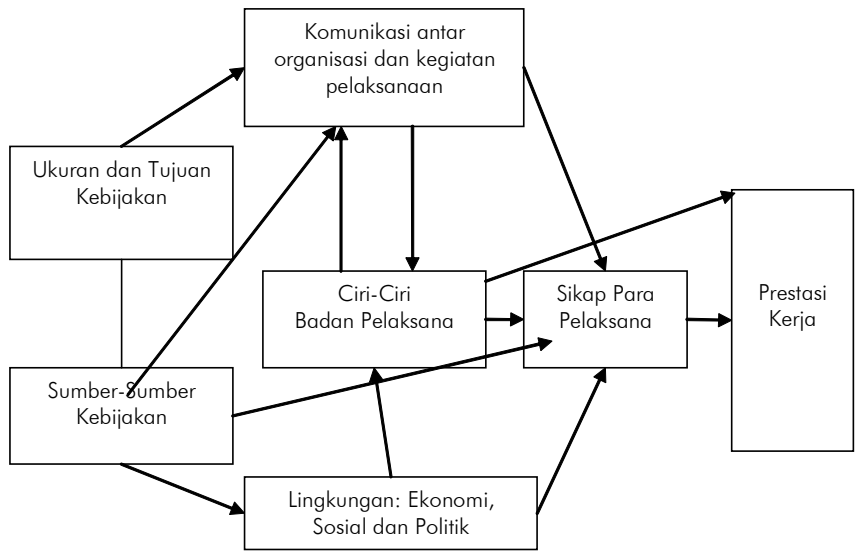

GAMBAR 2. MODEL IMPLEMENTASI VAN METER DAN VAN HORN

(Sumber: Mutiarin dan Zainudin, 2014: 26)

\section{MODEL GRINDEL (1980)}

Menurut Merilee. S. Grindel (1980) keberhasilan implementasi dipengaruhi oleh dua variabel besar, yakni isi kebijakan dan lingkungan implementasi (Suranto, 2014: 32). Variabel isi kebijakan (Content Policy) mencakup:

1) Sejauhmana dalam isi kebijakan.

2) Jenis manfaat yang diterima oleh target group.

3) Sejauhmana perubahan yang diinginkan dari sebuah kebijakan.

4) Apakah letak sebuah program sudah tepat.

5) Apakah sebuah kebijakan telah menyebutkan implementornya dengan rinci. 
2146) Apakah sebuah program didukung oleh sumber daya yang memadahi.

Sedangkan variabel lingkungan kebijakan (Contex Policy) mencakup:

1) Seberapa besar kekuasaan, kepentingan, dan strategi yang dimiliki oleh para aktor yang terlibat dalam implementasi kebijakan;

2) Karakteristik institusi dan rejim yang sedang berkuasa;

3) Tingkat kepatuhan dan responsivitas kelompok sasaran.

Secara sederhana model ini dapat digambarkan sebagai berikut:

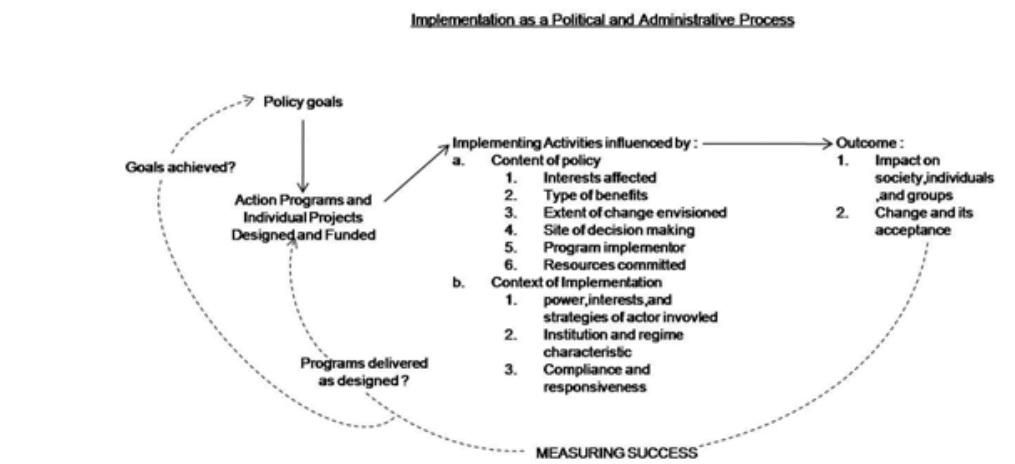

GAMBAR 3. MODEL IMPLEMENTASI KEBIJAKAN MENURUT MERILEE S . GRINDLE

D. MODEL MAZMANIAN DAN SABATIER

Menurut Mazmanian dan Sabatier (1981), ada tiga kelompok variable yang mempengaruhi keberhasilan implementasi yakni:

1) Karakteristik dari masalah.

2) Karakteristik kebijakan.

3) Variable lingkungan.

Yang dimaksud karakteristik dari masalah adalah:

a) Tingkat kesulitan teknis dari masalah yang bersangkutan.

b) Tingkat kemajemukan dari kelompok sasaran.

c) Proporsi kelompok sasaran terhadap total populasi.

d) Cakupan perubahan perilaku yang diharapkan.

Yang dimaksud karakteristik kebijakan adalah: 
a) Kejelasan isi kebijakan.

b) Seberapa jauh kebijakan tersebut memiliki dukungan teoritis.

c) Besarnya alokasi sumber daya finansial terhadap kebijakan tersebut.

d) Seberapa besar adanya keterpautan dan dukungan berbagai institusi pelaksana.

e) Kejelasan dan konsistensi aturan yang ada pada badan pelaksana.

f) Tingkat komitmen aparat terhadap tujuan kebijakan.

g) Seberapa luas akses kelompok-kelompok luar untuk berpartisipasi.

Yang dimaksud lingkungan kebijakan adalah:

a) Kondisi sosial ekonomi masyarakat dan tingkat kemajuan teknologi.

b) Dukungan publik terhadap sebuah kebijakan.

c) Sikap dari kelompok pemilih.

d) Tingkat komitmen dan ketrampilan dari aparat implementor.

Secara sederhana model tersebut dapat digambarkan seperti dalam Gambar 4.

Dari beberapa model implementsi kebijakan tersebut selanjutnya akan peneliti analisis untuk dijadikan kerangka teori dalam penelitian ini. Model Edwards III terdapat empat variable yang sangat menentukan keberhasilan implementasi suatu kebijakan, yaitu (1) komunikasi, (2) sumberdaya, (3) disposisi, dan (4) struktur birokrasi. Model ini menurut penulis kurang menyentuh fokus penelitian karena pada program $\mathrm{PKH}$ aspek manfaat yang diperoleh dari adanya program ini menjadi sub faktor dari variable isi kebijakan program PKH. Meskipun salah satu variable yang dikemukakan pada model ini juga dikemukakan pula oleh Grindle, namun dirasa masih kurang lengkap dan menyentuh fokus penelitian.

Model yang dikemukakan Daniel Mazmanian dan Paul Sabatier berpendapat bahwa peran yang penting dari implementasi kebijakan 
216 publik adalah kemampuannya dalam mengidentifikasi variablevariabel yang mempengaruhi tercapainya tujuan formal pada keseluruhan proses implementasi dengan pendekatan variablevariabel (1) mudah tidaknya masalah akan dilaksanakan, (2) kemampuan kebijakan menstruktur proses implementasi, (3) variable di luar kebijakan yang mempengaruhi proses implementasi, dan (4) tahapan dalam proses implementasi kebijakan. Menurut penulis model ini kurang tepat bila hal ini digunakan untuk melihat proses implementasi program $\mathrm{PKH}$ karena terlalu luas dan tidak menyentuh fokus penelitian terhadap program $\mathrm{PKH}$.

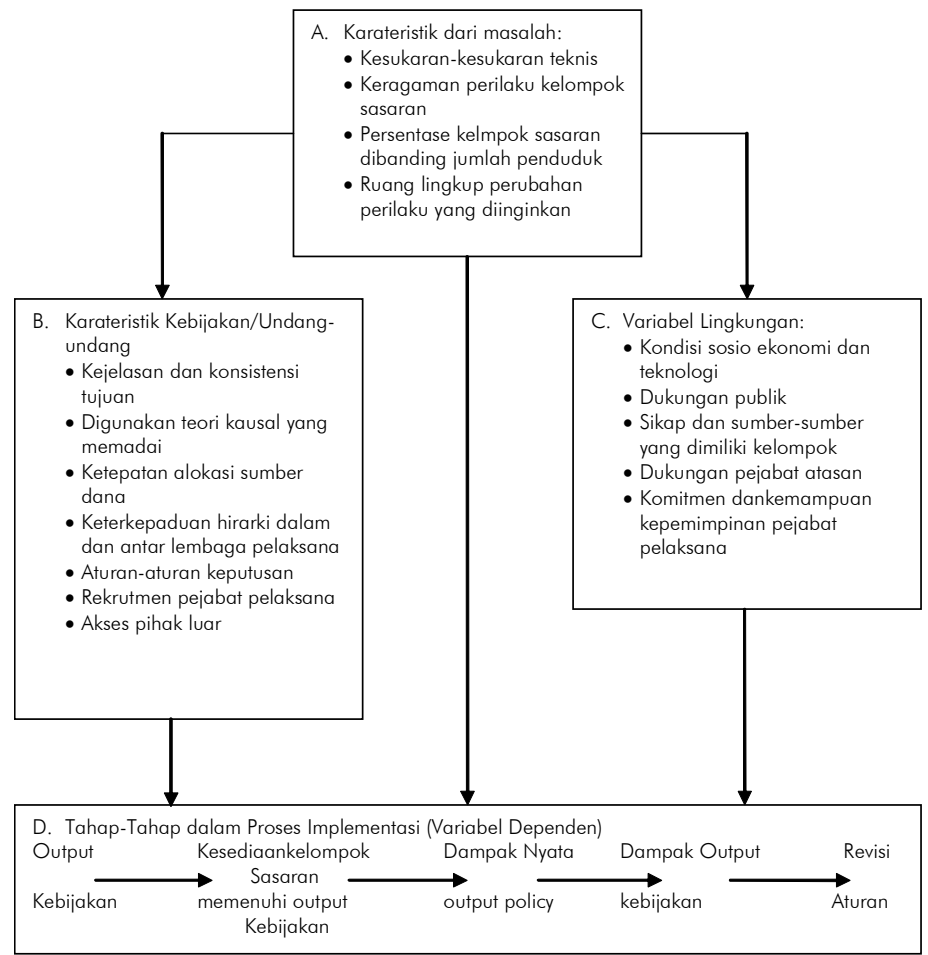

GAMBAR 4. MODEL IMPLEMENTASI SABATIER DAN MAZMANIAN

(Sumber: Mutiarin dan Zainudin, 2014: 29) 
Sedangkan pendekatan model Donald Van Meter dan Carl Van Horn mengandaikan bahwa implementasi kebijakan berjalan secara linier dari keputusan politik yang tersedia, pelaksana, dan kinerja kebijakan publik. Pada model ini menurut penulis dirasa kurang dapat mengakomodir variabel-variabel yang dapat digunakan untuk melihat proses implementasi kebijakan terutama pada aspek kepentingan yang didukung, manfaat program, serta derajat perubahan. Sedangkan pada model Grindle; menurut peneliti, jika dibandingkan dengan model-model top-down di atas lebih dapat menyentuh dan menganalisis implementasi program PKH dari aspek isi kebijakan dan konteks kebijakan. Model-model yang penulis kemukakan di atas merupakan model-model implementasi topdown.

Dalam penelitian ini penulis menggunakan penggabungan beberapa faktor yang mempengaruhi dari tiap-tiap model yang sinergi, dan salah satu model yang paling dominan digunakan adalah model Edwards III. Hasil penggabungan tersebut yang akan dipergunakan dalam penelitian ini adalah:

1. Tingkat Kepatuhan

Dalam hal ini untuk memahami aspek kepatuhan dilakukan dengan:

a. Melihat ada tidaknya aturan pelaksanaan.

b. Komitmen pelaksana akan aturan pelaksanaan yang ada.

c. Kepatuhan pelaksana dalam melaksanakan tahapan-tahapan pelaksanaan kegiatan.

2. Berbagai faktor yang dapat menjadi hambatan dalam pelaksanaaan yaitu:

a. Sumberdaya: baik berupa dana maupun sumberdaya manusia.

b. Komunikasi: baik komunikasi vertikal maupun horizontal.

c. Sikap pelaksana: meliputi sikap terhadap program dan sasaran program.

d. Kondisi sosial ekonomi. 


\section{METODE PENELITIAN}

Jenis penelitian ini adalah menggunakan pendekatan deskriptifkualitatif dengan menggunakan metode eksplanatori, yaitu salah satu metode kualitatif untuk mencari penjelasan fenomena yang diamati, masalah, atau perilaku. Penelitian ini memberikan sebuah penjelasan masalah yang diselidiki dengan menggambarkan kondisi subyek ataupun obyek penelitian dengan menjelaskan kedudukan serta hubungan antara variabel-variabel berdasarkan fakta-fakta yang tampak atau sebagaimana adanya.

Jenis penelitian ini adalah menggunakan pendekatan deskriptifkualitatif dengan menggunakan metode eksplanatori, yaitu salah satu metode kualitatif untuk mencari penjelasan fenomena yang diamati, masalah, atau perilaku. Penelitian ini memberikan sebuah penjelasan masalah yang diselidiki dengan menggambarkan kondisi subyek ataupun obyek penelitian dengan menjelaskan kedudukan serta hubungan antara variabel-variabel berdasarkan fakta-fakta yang tampak atau sebagaimana adanya.

Penelitian ini difokuskan pada implementasi Program Keluarga Harapan (PKH) di Kecamatan Berbah Kabupaten Sleman tahun 2013. Dalam penelitian kualitatif, analisis data dilakukan sejak awal penelitian dan selama proses penelitian dilaksanakan. Data yang diperoleh selanjutnya dikumpulkan untuk diolah secara sistematis. Dimulai dari wawancara, mengedit, mengklasifikasi, mereduksi, selanjutnya aktivitas penyajian data serta menyimpulkan data.

\section{PEMBAHASAN}

\section{IMPLEMENTASI PROGRAM PENANGGULANGAN} KEMISKINAN PKH DI KECAMATAN BERBAH TAHUN 2013

A. ATURAN PELAKSANAAN PROGRAM PENANGGULANGAN KEMISKINAN PKH

Program Keluarga Harapan (PKH) adalah program pemberian uang tunai kepada Rumah Tangga Sangat Miskin (RTSM) berdasarkan persyaratan dan ketentuan yang telah ditetapkan dengan 
melaksanakan kewajibannya. Program semacam ini secara internasional dikenal sebagai program conditional cash transfers (CCT) atau program Bantuan Tunai Bersyarat. Persyaratan tersebut dapat berupa kehadiran di fasilitas pendidikan (misalnya bagi anak usia sekolah), ataupun kehadiran di fasilitas kesehatan (misalnya bagi anak balita, atau bagi ibu hamil). Dalam pelaksanaan PKH di Kecamatan Berbah tahun 2013 terdapat aturan pelaksanaan.

Untuk aturan pelaksanaan PKH di Kecamatan Berbah selain aturan umum dari pusat, juga diwajibkan untuk mengikuti pertemuan kelompok, dan untuk aturan anggota kita serahkan ke forum (kelompok). Selain aturan yang sudah ditetapkan dari pemerintah pusat, juga ada peraturan yang ditetapkan oleh kelompok yang aturan pelaksanaannya diserahkan pada anggota kelompok (forum). Dengan demikian diharapkan kepada peserta PKH dapat melaksanakan program PKH dengan sebaik-baiknya sehingga program dapat berjalan dengan lancar dan tujuan program PKH dapat dicapai secara optimal.

\section{B. KOMITMEN PELAKSANA TERHADAP ATURAN PELAKSANANAAN $\mathrm{PKH}$}

Komitmen pelaksana terhadap aturan pelaksanaan PKH di kecamatan Berbah tahun 2013 sudah sangat baik. Komitmen yang dibuat sesuai dengan aturan pelaksanaan $\mathrm{PKH}$, sehingga dapat berjalan lancar dalam pelaksanaannya. komitmen pelaksana terhadap aturan pelaksanaan program PKH di Keamatan Berbah sudah sangat baik. Komitmen ini dibuat oleh peserta program PKH sendiri (forum), sedangkan ketua PKH tinggal mengawasi saja. Komitmen ini dapat berjalan selain dikarenakan dari sikap perserta juga karena adanya sanksi yang telah disepakati oleh anggota (forum). Dengan adanya komitmen dari peserta PKH ini maka pelaksanaan program PKH di Kecamatan Berbah tahun 2013 dapat berhasil dengan baik, yang ini dapat dibuktikan dengan diraihnya penghargaan sebagai juara TPK Award yang diadakan tingkat Kabupaten Sleman. 


\section{KEPATUHAN PELAKSANA DALAM MELAKSANAKAN TAHAPAN KEGIATAN PKH}

Kepatuhan pelaksana dalam melaksanakan tahapan kegiatan PKH di Kecamatan Berbah tahun 2013 sudah bagus, hal ini dapat dibuktikan dengan diperolehnya juara umum tingkat Kabupaten Sleman dalam Tingkat tim penanggulangan kemiskinan Award (TPK Award) tahun 2013 dan 2014. Kepatuhan dalam pelaksanaan PKH berhubungan dengan waktu, sehingga harus patuh terhadap tahapan-tahapan kegiatan PKH.

Sehingga dapat disimpulkan bahwa kepatuhan pelaksana dalam melaksanakan tahapan kegiatan program PKH di Kecamatan Berbah tahun 2013 sudah bagus, hal ini dapat dibuktikan dengan diraihnya juara umum tingkat Kabupaten Sleman dalam penanggulangan kemiskinan Award (TPK Award) tahun 2013 dan tahun 2014. Kepatuhan ini dilakukan dengan melaksanakan tahapan kegiatan sesuai dengan waktu yang sudah dijadwalkan.

\section{FAKTOR-FAKTOR YANG BERPERAN DALAM IMPLEMENTASI PROGRAM PENANGGULANGAN KEMISKINAN (PKH) DI KECAMATAN BERBAH TAHUN 2013}

A. SUMBERDAYA

Faktor yang mempengaruhi keberhasilan implementasi suatu kebijakan adalah sumberdaya. Sumberdaya merupakan hal penting lainnya, menurut George C. Edward III dalam Leo Agustino (2006: 151). Indikator sumber daya meliputi Staf, Informasi, Wewenang dan Fasilitas. Pada indikator staff pelaksanaan PKH bidang kesehatan di Kecamatan Berbah baik. Staf pelaksana PKH di Kecamatan Berbah terdiri dari Pendamping satu orang, dan posisi pendamping tidak hanya membawahi Kecamatan Berbah saja, melainkan juga membawahi kecamatan Depok. Hal ini dikarenakan jumlah peserta PKH diwilayah Kecamatan Berbah hanya 103 pada tahun 2013. Untuk sumber dana dengan menggunakan dana APBD I, APBD 
II, dan swadaya masyarakat. Dalam pendanaan di tingkat kecamatan diprogramkan dengan penguatan kelembagaan TPK, di tingkat desa dimasukkan dalam APBD untuk penguatan TPK melalui RPJM. Untuk dana pemberdayaan usaha-usaha kelompok dalam bidang ekonomi (dagang) dengan cara memasukkan proposal bantuan usaha ke kecamatan, sifat dana adalah bantuan simpan pinjam kepada kelompok.

Sehingga dapat disimpulkan bahwa faktor dana dalam implementasi kegiatan PKH di Kecamatan Berbah tahun 2013 berasal dari berbagai sumber yaitu: APBD I, APBD II, dan swadaya masyarakat. Dana ini kemudian dipergunakan untuk kegiatan perdayaan kelompok melalui TPK. Dengan demikian masalah dana dalam pelaksanaan implementasi PKH di Kecamatan Berbah tahun 2013 tidak ada kendala, bahwa dengan kesadaran sendiri mau melakukan swadaya untuk kegiatan-kegiatan pertemuan kelompok. Berkaitan dengan faktor sumberdaya manusia dalam implementasi pelaksanaan program PKH di Kecamatan Berbah tahun 2013 dari tingkat kecamatan sampai dengan tingkat pedukuhan sudah baik. Sehingga dalam pelaksanaan implementasi PKH di Kecamatan Berbah tahun 2013 dapat berjalan dengan lancar.

\section{B. KOMUNIKASI}

Faktor selanjutnya yang mempengaruhi keberhasilan implementasi suatu kebijakan menurut George C. Eward III, adalah komunikasi. Implementasi yang efektif terjadi apabila para pembuat keputusan sudah mengetahui apa yang akan mereka kerjakan. Pengetahuan atas apa yang akan mereka kerjakan dapat berjalan bila komunikasi berjalan dengan baik, sehingga setiap keputusan kebijakan dan peraturan implementasi harus dikomunikasikan kepada setiap bagian agar para implementor konsisten dalam melaksanakan setiap kebijakan yang akan diterapkan dalam masyarakat.

Dalam pelaksanaan program $\mathrm{PKH}$ di Kecamatan Berbah 
komunikasi dilakukan melalui pertemuan setiap tanggal 20 dengan istilah "Rembuk Nangkis" (terkait penanganan penanggulangan kemiskinan), untuk mensinergikan dengan program di organisasi yang ada di Kecamatan Berbah agar program tidak tumpang tindih. Sehingga dapat disimpulkan bahwa komunikasi yang dilakukan oleh TPK kepada peserta PKH dengan melakukan pertemuan dalam rangka pengeuatan kelembagaan setiap bulannya tanggal 20 . Kemudian juga dilakukan sinergi program dengan organisasi keagamaan (Aisyah) berkaitan dengan program penanggulangan kemiskinan yang dilakukan oleh organisasi keagamaan sehingga diharapkan program tidak tumpang tindih.

Komunikasi berkaitan dengan implementasi pelaksanaan program PKH di Kecamatan Berbah tahun 2013 berjalan dengan baik. Pihak kecamatan mengundang peserta $\mathrm{PKH}$ untuk rembukan perkembangan tentang pelaksanaan $\mathrm{PKH}$, dan diminta laporan yang ditujukan kepada kecamatan dan kabupaten. Sedangkan kalau ada permasalahan dikonsultasikan kepada Ketua PKH. Dengan demikian maka akan mempermudah implementasi pelaksanaan PKH di Kemacatan Berbah tahun 2013.

\section{SIKAP PELAKSANA}

Sikap pelaksana terhadap program dan sasaran program kegiatan PKH di kecamatan Berbah bagus karena terbukti di desa Tegaltirto ada warga yang mengembalikan KK miskin, ini membuktikan bahwa masyarakat sebenarnya juga semangat dan pelaksananya sendiri terutama didesa itu juga semangat.

Sehingga dapat disimpulkan bahwa sikap pelaksana progran $\mathrm{PKH}$ di Kecamatan Berbah tahun 2013 sudah bagus. Program PKH dilaksanakan sesuai dengan aturan yang sudah ditetapkan dan tidak ada unsur paksaan terhadap warga masyarakat. Apabila ditemui hal yang tidak sesuai dengan aturan pelaksanaan $\mathrm{PKH}$, segera dilakukan perbaikan dengan melakukan validasi data. Sikap pelaksana yang demikian ini akan mendorong implementasi program PKH menjadi 
lebih mudah dilaksanakan dimasyarakat.

D. KONDISI SOSIAL EKONOMI MASYARAKAT

Rendahnya kemampuan ekonomi masyarakat miskin menyebabkan tidak terpenuhinya kebutuhan pendidikan dan kesehatan bagi anak-anak RTSM. Maka PKH dimaksudkan untuk membantu RTSM memperoleh pelayanan pendidikan dan kesehatan yang memadai. Sehingga Penerima PKH adalah Rumah Tangga Sasaran dengan kondisi sangat miskin. Data peserta PKH tahun 2013 di kecamatan Berbah berjumlah 103 yang terdiri dari Sendangtirto 31 orang, Tegaltirto 19 orang, Jogotirto 26 orang, dan Kalitirto 27 orang. Adanya penurunan peserta PKH dari 115 orang pada tahun 2008 menjadi 103 orang pada tahun 2013 dikarenakan tidak mempunyai tanggungan dan pindah alamat, sehingga untuk menyikapinya dengan melakukan verifikasi ulang sebelum ditetapkan sebagai peserta $\mathrm{PKH}$.

Kondisi sosial ekonomi masyarakat di Kecamatan Berbah sudah mulai membaik sejak terjadinya bencana gempa 2006 antara lain disektor perdagangan. Hal ini dipengaruhi oleh di wilayah Kecamatan Berbah terdapat sentra-sentra petani ikan yang sudah bagus produksinya yang akan berpengaruh terhadap kondisi sosial ekonomi masyarakat. Dalam pendataan peserta $\mathrm{PKH}$ menggunakan data dari TNP2K yang datanya kurang akurat, sehingga dalam menentukan peserta $\mathrm{PKH}$ tidak tepat sasaran. Hal ini akan menghambat implementasi program PKH di Kecamatan Berbah tahun 2013. dalam pendataan peserta PKH menggunakan data dari TNP2K yang datanya kurang akurat, sehingga dalam menentukan peserta PKH tidak tepat sasaran. Hal ini akan menghambat implementasi program PKH di Kecamatan Berbah tahun 2013.

\section{KESIMPULAN}

Dari penelitian yang telah dilakukan peneliti tentang implementasi penanggulangan kemiskinan di kabupaten Sleman (Studi Kasus 
22 Program Keluarga Harapan (PKH) di Kecamatan Berbah) dapat disimpulkan bahwa:

1. Untuk memahami aspek kepatuhan dalam implemetasi program PKH di kecamatan Berbah dapat dilihat dari:

a. Aturan pelaksanaan PKH di kecamatan Berbah selain aturan umum dari pusat, juga diwajibkan untuk mengikuti pertemuan kelompok, dan untuk aturan anggota di serahkan ke forum (kelompok).

b. Komitmen pelaksana terhadap aturan pelaksanaan PKH di kecamatan Berbah tahun 2013 sudah sangat baik. Komitmen yang dibuat sesuai dengan aturan pelaksanaan $\mathrm{PKH}$, sehingga dapat berjalan lancar dalam pelaksanaannya. Selain itu, dari kelompok anggota ada juga yang mengusulkan untuk komitmen dengan sanksi uang, akan tetapi belum dilaksanakan.

c. Kepatuhan pelaksana dalam melaksanakan tahapan kegiatan PKH di kecamatan Berbah tahun 2013 sudah bagus, hal ini dapat dibuktikan dengan diperolehnya juara umum tingkat Kabupaten Sleman dalam Tingkat tim penanggulangan kemiskinan Award (TPK Award) tahun 2013 dan 2014.

2. Faktor yang berperan dalam implementasi program penanggulangan kemiskinan (PKH) di kecamatan Berbah tahun 2013

a. Sumberdaya

Staf pelaksana PKH di kecamatan Berbah terdiri dari pendamping satu orang, dan posisi pendamping tidak hanya membawahi kecamatan Berbah saja, melainkan juga membawahi kecamatan Depok. Hal ini dikarenakan jumlah peserta PKH diwilayah kecamatan Berbah hanya 103 pada tahun 2013. Untuk sumber danadengan menggunakan dana APBD I, APBD II, dan swadaya masyarakat. Dalam pendanaan di tingkat kecamatan diprogramkan dengan penguatan kelembagaan TPK, di tingkat desa dimasukkan dalam APBD 
untuk penguatan TPK melalui RPJM. Untuk dana pemberdayaan usaha-usaha kelompok dalam bidang ekonomi (dagang) dengan cara memasukkan proposal bantuan usaha ke kecamatan, sifat dana adalah bantuan simpan pinjam kepada kelompok. Untuk sumberdaya manusia dari tingkat kecamatan sampai dengan tingkat pedukuhan sudah baik.

b. Komunikasi

Dalam pelaksanaan program PKH di kecamatan Berbah komunikasi dilakukan melalui pertemuan setiap tanggal 20 dengan istilah "Rembuk Nangkis" (terkait penanganan penanggulangan kemiskinan), untuk mensinergikan dengan program di organisasi yang ada di kecamatan Berbah agar program tidak tumpang tindih. Untuk mengetahui perkembangan pelaksanaan program dengan rembugan tentang pelaksanaan serta mengundang peserta $\mathrm{PKH}$ untuk menyampaikan pertanggungjawaban dalam bentuk laporan ke kecamatan dan juga ke kabupatenUntuk mengetahui perkembangan pelaksanaan program dengan rembugan tentang pelaksanaan serta mengundang peserta PKH untuk menyampaikan pertanggungjawaban dalam bentuk laporan ke kecamatan dan juga ke kabupaten. Sesama pendamping kalau ada kegiatan saling bantu membantu, sedangkan kalau ada permasalahan dokoordinasikan ke ketua, dan apabila ketua PKH tidak dapat menyelesaikan kemudian dibawa ke UPPKH Kabupaten.

c. Sikap Pelaksana

Sikap pelaksana terhadap program dan sasaran program kegiatan PKH di kecamatan Berbah bagus sekali karena terbukti di desa Tegaltirto ada warga yang mengembalikan KK miskin, ini membuktikan bahwa masyarakat sebenarnya juga semangat dan pelaksananya sendiri terutama didesa itu juga semangat. Program PKH dilaksanakan sesuai dengan 
aturan yang sudah ditetapkan, meskipun pelan-pelan dan tidak ada paksaan terhadap warga masyarakat. Apabila ada kondisi di lapangan yang tidak sesuai dengan aturan pelaksanaan $\mathrm{PKH}$, maka segera dilakukan perbaikan dengan melakukan validasi data. Apabila ada kondisi di lapangan yang tidak sesuai dengan aturan pelaksanaan $\mathrm{PKH}$, maka segera dilakukan perbaikan dengan melakukan validasi data.

d. Kondisi Sosial Ekonomi Masyarakat

Kondisi sosial ekonomi warga masyarakat di kecamatan Berbah sudah mulai membaik sesudah terpuruk tahun 2006 saat gempa bumi, petani-petani ikan produksinya sudah bagus, sektor perdagangan juga sudah membaik. Dalam pendataan KK miskin menggunakan TNP2K itu memang datanya kurang akurat, ada yang seharusnya dapat malah tidak dapat sedangkan yang seharusnya tidak dapat malah dapat.

\section{DAFTAR PUSTAKA}

\section{BUKU}

Abdini, Chairil, (2012), "Poverty as Focal Concern of the Post 2015 Development Agenda, bahan masukan bagi Pertemuan HLPEP", Jakarta.

Bappeda Kabupaten Sleman, (2011), Rekapitulasi Hasil Validasi KK Miskin Tahun 2011 Dibandingkan dengan Tahun 2010, Sleman.

Bungin, Burhan, (2003), "Analisis Data Penelitian Kualitatif: Pemahaman Filosofisdan Metodologis ke Arah Penguasaan Model Aplikasi", Jakarta, PT Raja Grafindo Persada. Dunn, W.N., (1992), "Analisa Kebijaksanaan Publik", Yogyakarta: Hanindita graha widya. Indiahono, Dwiyanto, (2009),"Kebijakan Publik Berbasis Dynamic Policy Analysis" Yogyakarta, Gava media, 2009.

Kementerian Komunikasi dan Informasi RI, Program Penanggulangan Kemiskinan Kabinet Indonesia Bersatu II, Jakarta.

Komite Penanggulangan Kemiskinan Daerah Kabupaten Sleman, (2005),"Strategi

Penanggulangan Kemiskinan Daerah (SPKD) Kabupaten Sleman.

Mikkelsen, Britha, (2003),"Penelitian Partisipatoris dan Upaya-Upaya Pemberdayaan".

Terjemah: Matheos Nalle, Jakarta, Yayasan Obor Indonesia.

Moleong, Lexy J, (2004), "Metodologi Penelitian Kualitatif", Bandung: Penerbit PT Remaja

Rosdakarya.

Mubyarto, (2001), "Prospek Otonomi Daerah dan Perekonomian Indonesia Pasca Krisis 
Ekonomi", Yogyakarta: BPFE.

, "Penanggulangan Kemiskinan di Indonesia", Jurnal Ekonomi Rakyat, Th. 02/ April 2003.

Mutiarin, Dyah dan Arif Zainudin, (2014), "Manajemen Birokrasi dan Kebijakan: Penuluran Konsep dan Teori", Yogyakarta: Pustaka Pelajar.

Remi, Sutyastie Soemitro dan Prijono Tjiptoherijanto, (2002), "Kemiskinan danKetidakmerataan di Indonesia", Jakarta: Penerbit Rineka Cipta.

Sahdan, Gregorius, (2005), "Menanggulangi Kemiskinan Desa", Jurnal Ekonomi Rakyat, Ekonomi Rakyat dan Kemiskinan.

Shaffer, Paul, (2008), "New Thinking on Poverty: Implication for Globalisation and PovertyReduction Strategies", Article in Real-world Economics Review, Issue No. 47, 2008.

Sekretariat TNP2K, (2010), "Profil Tim Nasional Percepatan Penanggulangan Kemiskinan", Sleman.

Supriatna, Tjahya, (2000), "Strategi Pembangunan dan Kemiskinan", Jakarta: Penerbit Rineka Cipta.

Suryahadi, Asep, AthiaYumna, Umbu Reku Raya, and Deswanto Marbun , (2010), "Review of Government's Poverty Reduction Strategies, Policies, and Program in Indonesia, , Jakarta: SMERU Research Institute.

Sekretariat TNP2K, (2011), "Strategi dan Kebijakan Penanggulangan Kemiskinan Kabupaten Sleman 2011-2015", Sleman.

Tontowi, Ahmad, (2010), "Studi Implementasi Program Penanggulangan Kemiskinan Perkotaan (P2kp) di Desa Purbayan Kecamatan Baki Kabupaten Sukoharjo, TesisMAP, Surakarta: Universitas Sebelas Maret.

Firmanzah, (2012),"Penanggulangan Kemiskinan, Multi-Approach Strategy, www.setkab.go.id, November 2012.

Peraturan Presiden Nomor 7 Tahun 2005 tentang Rencana Pembangunan Jangka Menengah Nasional.

Undang-Undang Nomor 25 Tahun 2000 tentang Program Pembangunan Nasional.

\section{JURNAL}

Aneta, Asna, (2010), "Implementasi Kebijakan Program Penanggulangan Kemiskinan Perkotaan (P2KP) di Kota Gorontalo", Jurnal Administrasi Publik, Volume 1 No. 1 Thn. 2010.

Indarto, Sigit, (2014), "Analisis Dampak Kebijakan Pengintegrasian Program Penanggulangan Kemiskinan di Kabupaten Sleman Tahun 2012(Studi Kasus Kecamatan Prambanan dan Kecamatan Tempel"). Masters thesis, UPN "Veteran" Yogyakarta, Tesis UPN Veteran, Yogyakarta.

Sugiyana, Puji Meilita, (2012), "Implementasi Kebijakan Penanggulangan Kemiskinan Melalui Program Pemberdayaan Ekonomi Kelompok Usaha Bersama (KUBE) Di Jakarta Selatan, Tesis-MAP, Jakarta: Universitas Indonesia. 